問題は未だ研究す心゙き餘地を藏してるるるす 見るべきであらう。しかし而，上皮小體の 解剖學的位置は菜地氏の研究にあ如るく不定 で, 時沉臟の中沉さへあることを考へれば, 頸部々のみ之を求めて腺腫の有無を斷すること は慎まねばならぬことであるかも知れない。甲 狀腺腫支本疾患江見た例は少くないが，之を部 分的に切除することによつて, 輕快した報告は ない樣である。

\section{むす ひ}

私は本例の經過沉ついて斷定的判斷を下すべ さ確たる論據を見出し得ないがあら的療法寺 試みたるも見るべき效果のなかつた本疢の一重

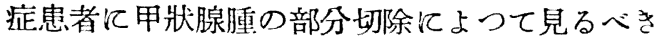
效果老收めた事實は報告の價值あるものと信す。 る次第である。
最後に, 終始御指導と, 本稿の御高閲卆賜つ

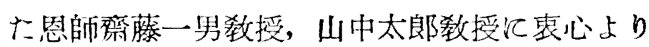
御禮を申し上げる。

\section{文献}

(1) Kienböck: Wien. Klin. Wochensehr. 1927. Nr. 5.

(2) " Fortschr. Röntgenstr., Bd 38.39,

(3) " Röntgendiagnostik der Knochenund Gelenkkrankheiten. Bd1. 1941.

(4) Stenholm T: Osteodystrophia fibrosa. Upsala 1924.

(5) Mandl,E; Archiv f. Klin. Chir. 55. 1897.

（6）松炕：日本整形外科舆既雜誌 5. (昭. 5)

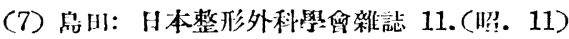

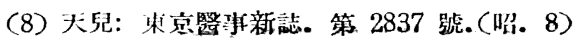

(9) 多听: 田日本整形外科學亚雜誌。(昭. 16)

\title{
脊椎骨折の一型について
}

One form of the Vertebral Fracture.

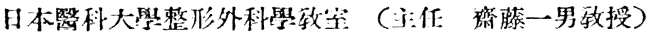 \\ 日本醫科大學放射称科學致空（主任 山中太郎教授）}

齋藤達

Saito Tatuo.

\section{緒言}

脊椎骨折往ついては, Kocher; Schanz; He-

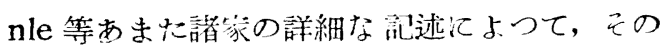
種類, 作用機䡜, 等は殆ど俆す所なく解明せら れてるる觀があるのでするが，それでも晌との

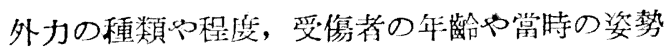
や個體差などの組合せによつて，その形が定型 的のものと湋つて來て, 時江吾々飞稀有な感を 抱かせるものがある。

こ、に報告せんとするものもとの一例であ る。

\section{症例}

淽 16 歲の男子 1949 年 4 月さる建設會社の 材木運搬場飞て仕事中, 約 20 米以上の上から 材木の束が十數東頭上江落下，下敷となり瞬間
直ちと意識袈失したと言ふ。

直ちに附近の䛦旗所に運ばれ，己こでは，頭 部の打撲裂㑺江加ふるに右大腿, 右腕關蓈の打

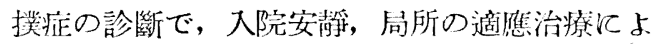
りン週間にて徒步退院したが, 步行時に足がよ く進まぬ自舅感がつよく，接骨師在訪れ揉み療 治を受けた。所がこンで, 棂椎に著明な側彎の あること在㻐見されたので，之啮する正確な 診斷と治療とを望んで上京, 受伤上り3週間目 に吾々の外來を訪れた。

當時, 全身狀態その他に特汇すべきことな く、春柱は强直や特被痛もなく溇動制限もない が, 腰椎下部に於て著明な左凸の侧彎兌呈し, 腰椎前彎が消失, その部の棘狀空起飞輕度の叨

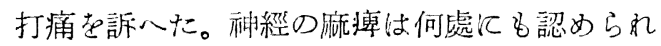


ないが步行は明ふな趼行走示し, 自覺的飞は右 の脚が短くなつた樣沉感すると訴えた。

X線立體寫基起撮影觀察した。（寫真 I II 寥 照) 第 N 㬴椎體の右後が崕潰せられた骨折, 第 VV欶狀空起の骨折，项び左側の第姆胁骨の骨

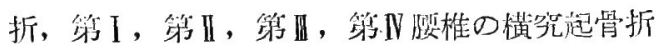

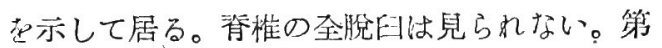

$\mathrm{IV}$ ，第 $\mathrm{V}$ 嘤湘間の惟閒板は右側がかへつて廣く
なつてるる樣化見えるが之は脊柱の捻轉が离 ためで西ろう。

受甥後すでに日起經て居り, 且つ幸にも脊髓 の損傷が認められぬので, 值ちに側等獢正位に てギプスコルセット裝着せしめたが，現在迄 の所經過良好で, 作業能力の障碍も目立た㨾 である。

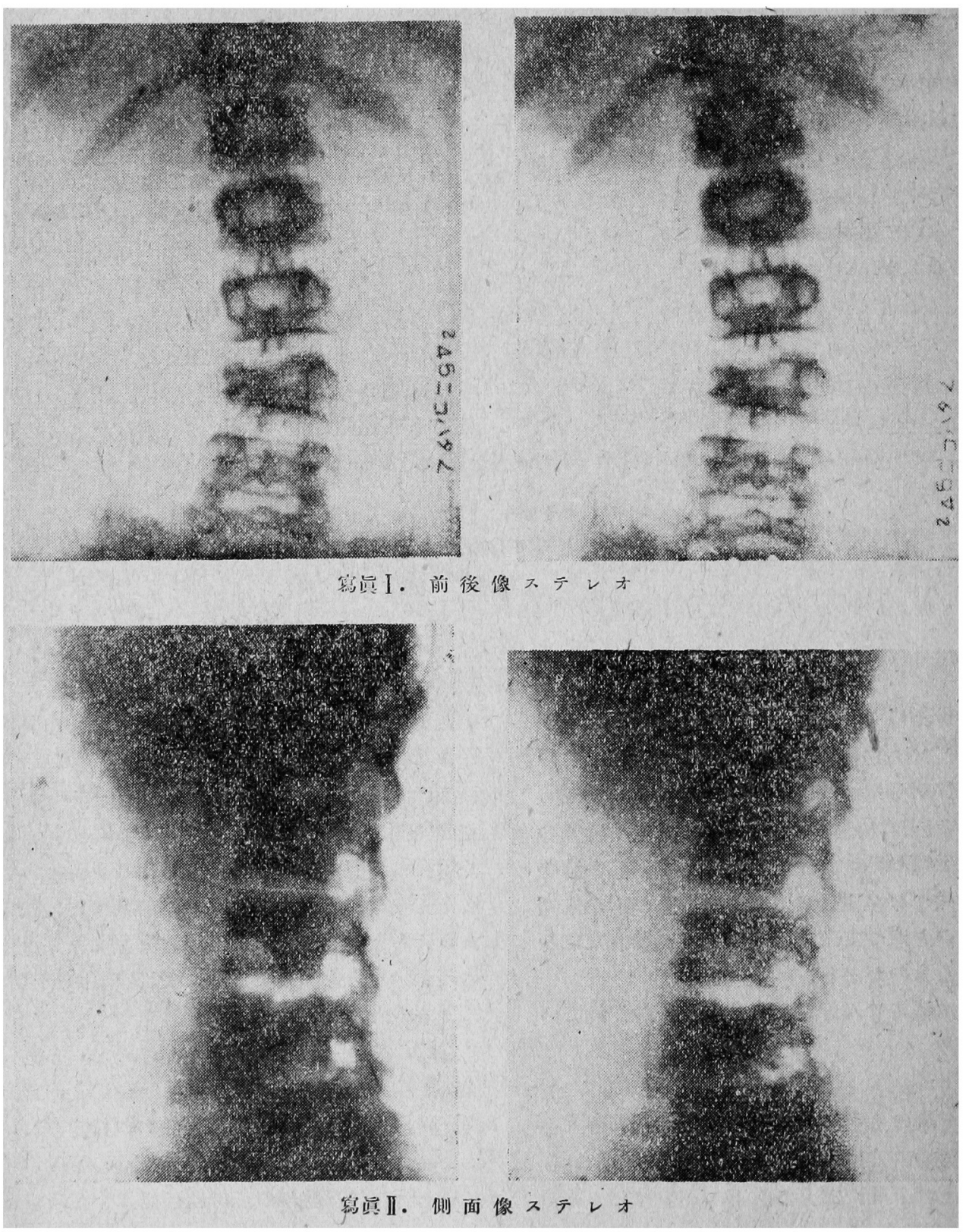




\section{考按}

周知の如く, 脊椎椎體の骨折機轉は普通

（1）脊柱の縱軸沉沿ふて上下汃ら壓迫され る瑒合

（2）相隣接せる椎體の相互に及ぶ槙杆作用

（3）以上飞加ふるに筋の隺引力

の三つの槛成分 (Komponente) が考へられる。 この三つは，しかも多くの場合沉，合同して同 時に働くもので, 惹起される骨折の型も殆ど一 定して，壓迫骨折方粉粹骨折で西るとせられる が，大部分は前線の壓緦せられた厴迫骨折で西 る。そしてこの嶎迫骨折は等柱の情造上第XII胸 椎から上部腰椎に多い理窟で离り, 症例も亦々 れを軗書きしてるることは述べるまでもないこ とである。

然ると本症例芭見ると，骨折起してるる椎

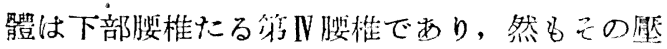
漬せられてるる部分は右牛分で严り，X線侧伯

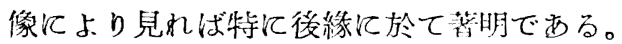

是緦の形も定型的な所謂る楔型といふ形では なく，右後の部分の階段狀の壓潰でする。

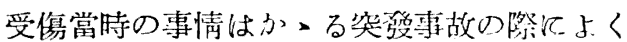
西る如く，患者が最初の僢間飞失心してるるた 内，全く自身江記憶のないことは前述の如くで

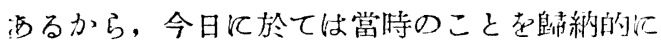
想像するより致し方がない。

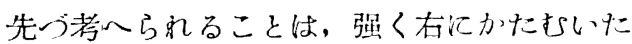
超生理的前屈運動であるが，之は右後汇階段状 飞出來た髾潰の形が率直にこのこと省穴させ ない。右とかたむいた前用であるなれば右前方 が潰れるべきである。然らば逆江右後うjへの们 杜の屈曲々いること考へることは肺すまで もなく䎽も考へ難いことで西る。又, 所謂る Stück-sprungsbruch 考考八ることは左斗分の 砣壦の少いのが不思議で西る。
そ己で，今，晋通に考へる心゙き先述の三つの Komponente の外飞思ひ切つて出て, 西らた めて, 細長い材木の束が 20 米高所沉より降つ て來た受傷當㭙の模樣苍考へてみると, 右斗分 の椎體飞骨折が限局的飞强いこと, 瓷椎の全脫 曰が見られぬにも拘らす棘壯突起の骨折がある ことから, 之は外力が直接邪 N 腰檴の方向江右 後方から銃く加つてその部分飞爆弡的に働いた のではないかと，强いて侾いられぬこともなさ

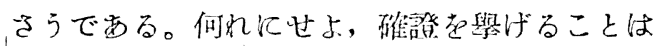
困嫨である゙。

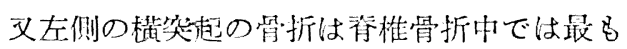
多く起るもので，2做又は腰椎全部の連續した 骨折も，珍しくない橙であるが，本例の如く

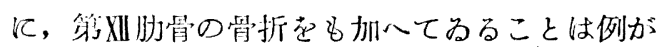
少いのである。

$$
\text { むすび }
$$

こ・に, 私は, 奉椎及體骨折の一例で, その 原潰の部位及び狀態が非定型的であるためにこ の管折作朋機轉の解釋几困難を感じたもの范報 告し, 更に之に對する一解䆁芷行つてみた次第 である。

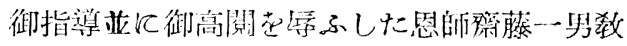
授山中太郎敉授汇㫗く御禮莡申上げる。

(昭和 24 年 7 月整形外科集談會化報告)

\section{文 献}

(1) Matti: Knochen Brüche. 1931.

(2) Henle: (hirurgie d. Wirbclsäule; 2 Abschnitt in Handbuch der pralst. (hir. 1922.

(3) Lange: Lehrbuch der Orthopädie. 1958.

(4) Key \& Conwell: Fractures Dislocations and. Siprains.

(5) 科中: 整形外利舆

(6) 闬：少折治诲点

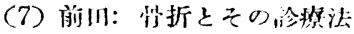

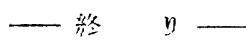

